\title{
From Society to Federation: International Collaboration in Artificial Organs Research
}

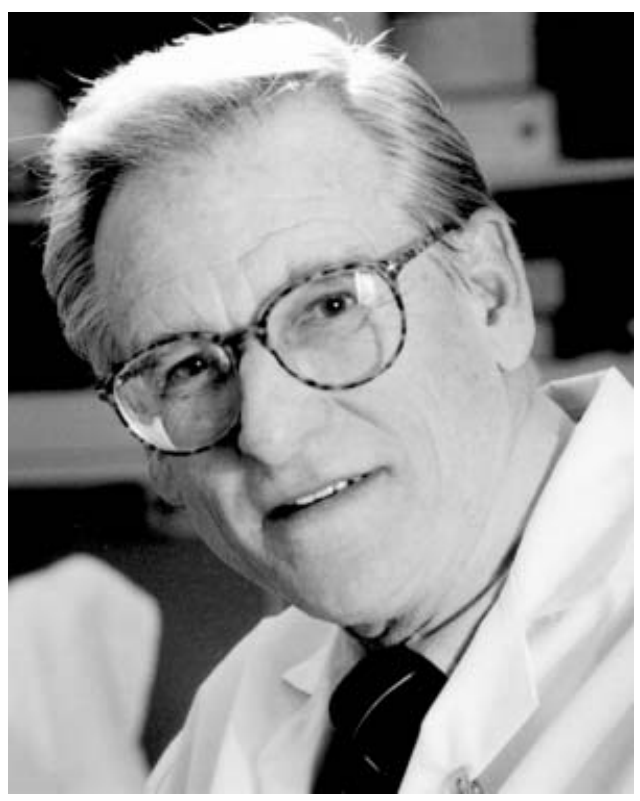

At the joint ASAIO-ISAO meeting in June 2003, the Executive Committee, the Board of Trustees, and general membership of the International Society for Artificial Organs (ISAO) unanimously approved a constitutional amendment designed to facilitate and guarantee the noble goals of the ISAO far into the future. Those goals are to support participation and communication in artificial organ research throughout the world by providing communication, education, and publication in our exciting field of organ replacement. The means to accomplish these goals which had been served so well during the first decades of the ISAO are modified by the constitutional amendment to reflect communication and participation in the 21st century. The new format is a win-win situation for all scientists and clinicians to participate in the development and use of artificial organs.

The International Society for Artificial Organs was founded in 1977 by Yukihiko Nosé and Horst Klinkmann and other pioneers in those early days of artificial organ research. The goals listed above were defined and the methods of communication, regular meetings, publications, and education were established through several mechanisms. The journal Artificial Organs was organized and has become very successful. The International Faculty for Artificial Organs was established and provides both education and advanced degrees in artificial organ science throughout the world. Membership was available to scientists from all countries and all continents. The initial meetings were held in conjunction with the major national societies and other artificial organ research organizations. During the last decade, the meetings have been held as individual freestanding meetings, the journal has gone to monthly publication, and the membership has increased to a high of approximately 800 members. During this same time period, the American Society for Artificial Internal Organs (ASAIO), the European Society for Artificial Organs, and the Japanese Society for Artificial Organs have similarly grown in membership, publications, annual meetings, and communication.

Research in organ replacement (itself only 50 years old) follows a natural cycle from very basic bioengineering to early clinical trials to routine clinical practice. The artificial organ societies serve as the incubator and facilitator for the first two purposes. However, as artificial organ application becomes routine clinical practice, scientific reports of clinical practice move to organ-based clinical societies. Society membership, publication, and industry exhibitor interest moves to the clinical societies as well. In our field, this happened long ago with cardiac surgery, joint replacement, and blood vessel replacement. In the last 20 years, this phenomenon has happened with intermittent therapy for renal failure. Everyone in artificial organ research can take great pride in these accomplishments which have prolonged and improved the lives of hundreds of thousands of patients around the world. However, the practicalities of serving the membership, holding annual meetings, and providing worthwhile publications become difficult as each organ replacement project moves from research to routine clinical practice. 
Although the artificial organ societies still serve as the meeting point for those who are improving heart surgery, hemodialysis, vascular grafts, etc., the exciting research these days is in implantable organs, biohybrid devices, and replacement of organ function which does not exist clinically (neurologic, endocrine, liver, gut prostheses). When each major artificial organ application moves to clinical societies and journals, the artificial organ research society meetings become smaller and more difficult to support (but in my opinion much more interesting and exciting), then the next major organ replacement begins to grow and the research meetings boom until that topic moves to routine clinical practice. This is happening now with acute liver replacement for example.

Another characteristic of artificial organ research is that the investigators working in very small but intense areas find it useful to meet and publish research done by a few laboratories in very specific areas. This activity invariably leads to the formation of small "societies" or research clubs and meetings such as the Extracorporeal Life Support Organization focused on treatment of respiratory failure, the Apheresis Society focused on applications of plasmapheresis, annual meetings such as the Continuous Renal Replacement Therapy meeting focused on specific technology, and the International Society for Rotary Blood Pumps-very esoteric. The Implantable Lung Club which consists of researchers from four laboratories has now evolved to the position of a workshop at the ASAIO meeting. It is not hard to imagine an artificial vision and hearing society, an artificial blood society, or a renal tissue engineering society. Each of these little clubs or meetings needs an organizer, then an office, then a newsletter, then a journal, then an executive secretary, then industrial support, then invited lecturers, then named awards, medallions, and fellowships, then more industrial support, etc., etc. These clubs tend to become the regional (Scandinavian, Japanese, African, American, European) Society of Interesting Topic, leading ultimately to the establishment of the International Society of Interesting Topic. All this occurs in the name of research on organ replacement.

In 1998, a Task Force was established to examine the future of ISAO in light of this natural history of artificial organ research. Attendance at the ISAO freestanding meetings was not very good. Almost all members of ISAO also belonged to one of the major regional societies so there was inherent competition for presentations and attendance at meetings and publication of scientific papers. In individual laboratories these decisions are based on finances, travel costs, readership and prestige of specific journals, and the scientific benefit and cross-fertilization available at various gatherings. The members of the Task Force analyzed all of these factors as they related to the goals and recommended that ISAO take the first step toward consolidation of artificial organ research activities. Putting strong egos aside, the leaders of ISAO recognized that the goals could be better served as a Federation of the major existing societies. The goals could be better served without a central office, an expensive annual meeting, or a subsidized journal. Individual artificial organ laboratories and researchers could get more benefit from their personal membership dues and journal subscriptions if the international emphasis was achieved through a federation of the strong regional societies. An amendment to the constitution of ISAO was drafted and developed to achieve this consolidation. The governance, the meeting format, and the financial arrangements were worked in a way that is beneficial to all concerned. That constitutional amendment and the policies for implementing the new format will be published in an upcoming issue of Artificial Organs. The new format will be tested in the form of bi-annual meetings with the three member societies of the Federation over the next six years, and then reevaluated. The Board of ISAO believes this is a very positive step toward strengthening and consolidating communication and participation in artificial organ research. The legacy of the pioneer organizers of ISAO will be assured and continued long into the future.

Robert H. Bartlett, MD
President, International Society for Artificial Organs
Professor of Surgery
University of Michigan Health Systems
1500 E. Medical Center Drive, 2920 Taubman Ctr.
Ann Arbor, MI 48109, USA
E-mail: robbar@umich.edu

